\title{
Learner Acquisition and Its Relationship with Constructivist Learner Roles in a Secondary Education Chemistry Curriculum in Québec/Canada
}

\author{
Abdullah Aydın ${ }^{1}$ \\ ${ }^{1}$ Faculty of Education, Department of Science Teacher Education, Ahi Evran University, Kırşehir, Turkey \\ Correspondence: Abdulah Aydın, Eğitim Fakültesi, Fen Bilgisi Öğretmenliği Anabilim Dalı, Ahi Evran \\ Üniversitesi, Terme Cad., Kırşehir, Turkey. Tel: 90-505-487-4471. E-mail: aaydinch@gmail.com
}

Received: April 6, 2013 Accepted: May 6, 2013 Online Published: June 24, 2013

doi:10.5539/ies.v6n7p88 URL: http://dx.doi.org/10.5539/ies.v6n7p88

\begin{abstract}
This study aims to identify constructivist learner roles in acquisitions in the secondary education chemistry curriculum of the province of Québec / Canada. This research used document analysis as a qualitative research method. According to our findings; the "learner roles" in curriculum correspond with the "student roles" emphasized by the program. We found that these overlaps mostly cohere with "constructive learner roles". These cohering constructive learner roles are i) the individual takes the control of the learning process, ii) the individual is selective, constructive and active in the learning process, iii) the individual carries out his/her responsibilities in constructive learning environments,iv) the individual, constructs a meaning in his/her mind for knowledge acquired in the construction process and appropriates that knowledge, v) the individual communicates and discusses issues with other learners and teachers. Moreover, a clue indicating that a History-Technology-Society perspective was used as a background framework for generating the special approaches and goals for science learning has been encountered in the assumption of the constructivist learner roles. This clue is a quote from Albert Einstein: "Every day I remind myself that my inner and outer life are based on the labors of other men, living and dead, and that I must exert myself in order to give in the same measure as I have received and am still receiving" This clue can be generalized to the contribution of education programs to teaching programs / the contribution of chemistry program to the educational program.
\end{abstract}

Keywords: secondary education chemistry curriculum, constructivist learner roles, learner acquisitions

\section{Introduction}

When we analyze the theories in the field of teaching and learning, we see that these theories can be classified as objectivist and constructivist (Deryakulu, 2001). The objectivist view in education is represented by behaviorist and cognitive theories. These theories concentrate on the arrangement of the outer world more than the inner world of the students and individual differences (Deryakulu, 2001). While objectivist theories focus on the observable macroscopic features of learners, the constructivist approach concentrates on the unobservable inner world of individuals. Constructive learning theory gives prominence to individual's critical thinking, investigation, problem-solving and entrepreneurship (Brooks \& Brooks, 1993; Marlowe \& Page, 1998). Their prominence, primarily, depends on environments where constructive approach is applied successfully and places where real democracy is experienced. In short, it depends on the creation of a constructive classroom atmosphere. In these atmospheres, both instructor and learner work actively (Akar \& Y1ldırım, 2004). At this point, the role of the learner is not to acquire information as it is, but to produce or search for it. Thus the learner is not passive but active (Akar \& Yıldırım, 2004). This activeness takes the form of students contribution to the learning environment by investigating, making mental efforts, searching, questioning facts that are known or presented, interacting with others, and developing innovative attitudes (Deryakulu, 2000). The contribution can be obtained by programs that are a recipe for learning (Taba, 1962; Oliver, 1971). In this recipe, the learner is the center and the builder of his/her own knowledge (Piaget, 1926); cited by [Gustave, 2003: 36]. Its architecture is the constructivist approach which has been called a worldwide "movement" (Erickson, 2001). 
The educational program based on the constructivist approach is a world-wide phenomenon (Avenstrup, 2004). Constructivism continues to be the dominant research program in (at least) science education and it continues to generate new research and insights (Baker, 2007).

A study conducted by Aydin (2012: 144), states that the "constructivist learning approach" and the way of "life based learning" were chosen by Québec's secondary education chemistry curriculum. In other words, we understand that they adopted thinking and prefer to think with "analogies" the - wings of thinking. In Québec, the skills thus acquired are seen gained as "the contribution of chemistry program to the educational program". It is emphasized that learners are central in this teaching program (Programme de Formation de l' École Québécoise) [PFÉQ]. This emphasis ensures that the skills listed in Appendix 1 are acquired by students throughout the province.

Moreover, the city's, History-Technology-Society (H-T-S) perspective is a special approach to -science learning that extends the students' range of skills beyond those presented in Appendix 1. According to this perspective;

"Due to the increasing emphasis on physics in secondary education, this chemistry program wants to get learners to create relationships between theoretical concepts, and the interaction of context, science and technology in the exploration of these concepts is maintained for years. The results of scientific discoveries or technological applications have affected both human life and the environment. This is what authors call H-T-S. This was selected as our specific approach to science learning and as a background framework and in order to determine our goals." (Marois, 1998: 5).

Considering this phenomenon (Avenstrup, 2004) in terms of philosophy of education, we understand that it supports the interpretation of knowledge (Yıldırım \& Şimşek, 1999) and the construction of knowledge on the basis of discussion and reflection (Vygotsky, 1994). Such, knowledge is subjective (Bağc1 \& Kılıç, 2001). Learning is related to the life of a person, their social fabric and their experiences (Akar \& Ylldırım, 2004). These points make, it clear that constructivism is a theory of learning (Brooks \& Brooks, 1993). Constructivist learning theory gives prominence to individuals' critical thinking, questioning, problem solving and entrepreneurship (Brooks \& Brooks, 1993; Marlowe \& Page, 1998). The theory needs students' active participation inside and outside the classroom (Ülgen, 1994; Akar \& Yıldırım, 2004; Taber, 2006; Gürdal \& Gönen, 2010). In this learning process, the student understands the importance of taking responsibility and participating in decision - making (Brooks \& Brooks, 1993; Akar \& Yıldırım, 2004) and behaves accordingly (Akar \& Ylldırım, 2004). When an individual learns, s/he helps to construct new knowledge by sharing past knowledge and experiences using the methods of discussion and reflection (Shunk, 1996). Knowledge acquisition is not an outcome, but it is a resource for the construction of a new knowledge (Akar \& Yıldırım, 2004).

\subsection{The Roles of Constructivist Learner}

It has been claimed that there are three different learner roles (Yaşar, 2010: 17) active (Ülgen, 1994; Akar \& Y1ldırım, 2004; Taber, 2006; Gürdal \& Gönen, 2010), social (Perkins, 1999) and creative (Ülgen, 1994: 177). In the constructivist learning approach, learning is carried out by active participation in processes such as discussion, defending opinions, forming hypotheses, questioning and sharing opinions (Yaşar, 2010: 17). From this active participation, we can obtain clues about Albert Einstein's quote "Free your mind and think" [FMT] and Jean Paul Sartre's "Man is condemned to be free" [MCF].

This learning approach also emphasizes that knowledge and meaning is constructed socially by interacting with other individuals besides individual undertakes an active role in learning process (Yaşar, 2010: 17). In this learning approach, learning is generally carried out as group work in learner's social role (Ülgen, 1994: 177-178; Perkins, 1999). From that social role, we can reach clues about the statement "the aim of the individuals grewup in constructivist learning environments is to be themselves, but to share the world with others" (Deryakulu, 2001).

In this learning approach, the creative role of the learner is about activities such as remembering, recoding the perceptions, creation (producing new products), and maintaining learning in cooperation with group members, and learning style and strategies (Ülgen, 1994: 177). Learners try to learn by discussing different solutions or exploring in constructive classrooms. In evaluation process, they act critically as much as possible and try to be active (Yaşar, 2010:17). From that point, we can reach clues about Karl Popper's statement "Life is to Solve the Problem" [LSP].

The behaviors students are expected to demonstrate in constructive educational environments are presented as (Savery \& Duffy, 1996; cited by Yaşar, 2010: 18; Yaşar, 1998:698); 
- To be active in the educational environment.

- To assume responsibility in the learning process.

- $\quad$ To benefit from very opportunity and possibility.

- To evaluate themselves and the group members they work with objectively.

- To accept every criticism of themselves with tolerance.

- To apply what they learn to a new environment.

- $\quad$ To use knowledge sources and teaching materials.

Accordingly, it is obvious for a learner who carries out such a learning process to know "The Role of Constructive Learner" in this teaching program. That work is important for all these reasons.

\subsection{Statement of Problem}

In the study carried out by Aydın (2012: 144); it was determined that the "constructivist learning approach" and the "life-based learning" model are adopted in the secondary education chemistry curriculum in Québec / Canada. Are "constructivist learner roles" emphasized or implied in the above-mentioned program? If they are, what is the background framework in the appropriation of these emphases and implications? Answers were sought specifically to these questions.

\subsection{Theoretical Framework}

If we want to earn respect in the world, there is no option other than being a person who learns, an organization that learns and a nation that learns (Gündoğdu, 2010: 2). This can only be done by people improving their mind, not by filling their memories [Mark Twain] [Demle] [D]. In other words, it depends on the adoption of the constructivist approach which focuses on what children can produce and perform not what they can repeat (Brooks \&Brooks, 2001: 16); cited by [Kaya, Tüfekçi and Bilasa, 2010: 20]. This approach focuses on learning to learn. Specifically, learning to learn means that an individual gains learning skills by solving problems (Ülgen, 1994: 177). In other words, learning to learn is to manage, to direct what will be learned, and to know what is learned and why (Inam, 2012). The learner is in the center in constructive theory and the builder of his/her knowledge (Piaget, 1926); cited by [Gustave, 2003: 36]. According to this approach, learner is the person who learns to learn (Treagust et al., 1996; Martin, 1997); cited by [Orhan, 2007: 29].

The first root of this learning program is based on the philosophy of Socrates (Şişman, 2010: 4); Other roots include the philosophy of Kant and the thought of Giambattista Vico an eighteenth century Italian philosopher (von Glasersfeld, 1995; Tynjala, 1999); cited by [Orhan , 2007: 30]. According to learning theory (Brooks \& Brooks, 1993), in other words, according to information theory (Şişman, 2010: 4) or epistemology (Gürdal and Gönen, 2010), the learner designs interior decoration or, in other words, "his/her mind that is the place of things" [Kant] (Yalçın, 2012). Namely, the design is a process of building a meaning, and it takes place in the mind [Eflatun \& Kant] (Şişman, 2010: 7). When a learner participates actively in building meaning, learning occurs (Wood, 1995: 334); cited by [Kaya, Tüfekçi and Bilasa, 2010: 20]. This active participation takes the form of relating prior knowledge to new situations (Driver, 1995: 399); cited by [Kaya, Tüfekçi and Bilasa, 2010: 20]. This association is in the form that learners construct their own intrepretation about their situation (Wood, 1995: 334); cited by [Kaya, Tüfekçi and Bilasa, 2010: 20]. The construction of interpretations depends on learners' appropriation of problem, studying and the process of constructing a solution (Savery and Duffy, 1996: 137140); cited by [Kaya, Tüfekçi and Bilasa, 2010: 20]. In other words, it claims that learners should consider (Savery and Duffy, 1996: 137- 140); cited by [Kaya, Tüfekçi and Bilasa, 2010: 20] both what is learned and learning strategies - drama, project works, learning by designing, learning by teaching, cooperative learning (Wilson, 1997: 8); cited by [Şaşan, 2002] and that knowledge develops in social atmospheres (Driver, Asoko, Leach, Mortimer and Scott, 1995); cited by [Larson, 1996: 2].

In this design process, "learners should know what his/her learning responsibilities are and the importance of learning them in a sequential order; and that he/she is responsible for the learning activities" (Ülgen, 1994: 174). Specifically, the learner should know "learner roles", since an individual places "things" into "the mind which is the place of things" [Kant] (Yalçın, 2012) with thoughts [Socrates \& Einstein] (Yıldırım, 2009; Güran, 2011) by using analogies which are the wings of thought (Aydin, 2012: 159). S/he sees the "things" with "thought" [Hegel] (Yalçın, 2012). Thus, individuals are selective, constructive and active in the learning process (Ülgen, 1994: 144). Accordingly, the individual shoulders the responsibility for learning and sees each individual as another separate source for learning (Lev Vygotsky (1896-1934); cited by [Şişman, 2010: 4]. The learner acquires knowledge, skills and experience through these sources. These acquisitions are called "learner acquisitions" or 
"learning acquisitions". A learning acquisition refers to expressions that determine what a learner knows, comprehends and/or becomes capable of doing at the end of the process of learning (Donnelly \& Fitzmaurice, 2005: 16); cited by [Khoza, 2013: 1]. They are expressions about knowledge, skills and attitudes.

To achieve learning as a lifelong "job", an individual should "learn to learn" and know "learner roles". This study is important for all these reasons.

\subsection{The Aim of the Study}

In this study, we aimed to identify constructivist learner roles in learner acquisitions in the secondary education chemistry curriculum of the province of Québec / Canada.

\subsection{Research Questions}

Québec / Canada in the scope of this research;

(i) Are "learner roles" described as learning acquisitions of the secondary education chemistry curriculum?

(ii) Are "learner roles" emphasized in secondary education chemistry curriculum?

(iii) Do "constructive learner roles" cohere with "learner roles" "described" as learning acquisitions in the curriculum?

(iv) Do "constructive learner roles" cohere with "learner roles" "emphasized in the curriculum?

And, if "constructivist learner roles" are implied or emphasized;

What is the background framework in the appropriation of these emphases and implications?

\section{Method}

In this research, we used document analysis as a qualitative research method. This method is applied in order to identify "certain words or conceptions in a mass formed of text or texts" (Büyüköztürk, Çakmak, Akgün, Karadeniz \& Demirel, 2008: 253). The method is currently widely used in the field of social sciences (Yildirım \& Şimşek, 1999: 150). Document analysis involves analysis of written materials including information about phenomenon under investigation (Yıldırım \& Şimşek, 2004). Québec secondary education chemistry curriculum (PFÉQ) was examined through the above-mentioned method. The most important disadvantage of document analysis is coding difficulty. To overcome this, we used a "constructive learner roles" chart created by the researcher on the basis of a review of the literature analyzing these "learner roles" emphasized in teaching programs presented in Appendix 1 and "learner roles" implied in learning acquisitions in the same program (Appendix 2).

\section{Discussion of Findings}

It is emphasized that learners are central in pointed teaching program of the province [PFÉQ]. In this emphasis, the following skills are gained to the students in the center from the center to the outer [PFÉQ] (Appendix-1a-1e). Table 1 presents the "learner roles" (PFEW, p. 11) in Québec's teaching program.

Appendix-1a. Learner acquisitions of Québec city in Canada in "the frame of educational program"

\begin{tabular}{l}
\hline Student \\
\hline Construction of identity \\
Building a world view \\
Improving operational power \\
\hline
\end{tabular}

The table shows that in this teaching program the acquisition of the skill "building a world view" is a desired outcome for the students. The skill "involves a learning process together with his/her teacher, but $\mathrm{s} / \mathrm{he}$ takes the control of learning and s/he makes the decisions" (Brooks \& Brooks, 1993). On the other hand, with the acquisition of that skill, we obtain a clue that "the learner has own individual ideas about the world" (Taber, 2006). From that point, we can understand that what is being sought here is an active learner profile that can relate new events with different situations and produce new results and ideas (Gürdal \& Önen, 2010). The province's teaching program offers a clue about Albert Einstein's expression "Free your mind and think" [FMT]. With acquisition of skill in "improving operational power", we get a clue about the "active construction of the knowledge by the learner" (Taber, 2006) and we can also begin to comprehend Paul Sartre's quote: "Man is 
condemned to be free" [MCF]. This point makes it clear that individuals have control over their learning experience (Brooks \& Brooks, 1993; Akar \& Yıldırım, 2004).

Appendix-1b. Québec's learner acquisitions in "general fields of education"

\begin{tabular}{l}
\hline Media \\
\hline Environment and consumption \\
Entrepreneurship and guidance \\
Health and wealth \\
Living together and citizenship \\
\hline
\end{tabular}

This table shows that this teaching program, tries to impart to learners the skill of being the target himself/herself but sharing the world with others equally (Deryakulu, 2001). It is understood that the individual is selective, constructive and active in the learning process (Ülgen, 1994: 144).

Appendix-1c. Québec's learner acquisitions in "transversal skills"

\begin{tabular}{l}
\hline Communication Skills \\
\hline Communicating properly \\
Personal and Social Skills \\
Realization of potential \\
Cooperation \\
Methodological Skills \\
Exploring information and communication technologies \\
Using effective study methods \\
Intellectual Skills \\
Exploring knowledge \\
Solving problems \\
Using critical judgement \\
Putting creative thinking into practice \\
\hline
\end{tabular}

This table shows that the teaching program, tries to impart the skill being an entrepreneur in the learning environment, expressing himself/herself, communicating, being critical, planning, and using what s/he has learned in life (Brooks \& Brooks, 1993; Marlowe \& Page, 1998). This point means, that the individual carries out his/her responsibilities in the learning environment (Savery \& Duffy, 1996; cited by Yaşar, 2010: 18; Yaşar, 1998: 698).

Appendix-1d. Québec's learner acquisitions in "chemistry associated learning fields"

\begin{tabular}{l}
\hline Mathematics, Science and Technology \\
\hline Social Universe \\
Art \\
\hline
\end{tabular}


Personal Development

Career Development

Languages

This table shows that the teaching program tries to get the learner to learn the skill learn as s/he constructs learning in their minds, not as presented to him/her (Yaşar, 1998: 698). In other words, it is understood that it is tried to get the learner gain the skill about that individual tries to construct a meaning for knowledge and to appropriate it (Orhan, 2007). We can understand that, in construction process, individual tries to construct a meaning for knowledge and to appropriate this knowledge (Yaşar, 2010: 17).

Appendix-1e. Québec's learner acquisitions in "chemistry disciplinary skills"

To solve problems related to chemistry and searching for the answers

To benefit from the knowledge of chemistry

To communicate on chemistry questions with the help of languages used in Science and Technology

This table shows that the teaching program, tries to teach the skill by means of which the learner always communicates, discusses, criticizes and asks constructive questions to have an effective role in learning process (Lind et al., 1996: 211); cited by [Şaşan, 2002]. This point means, that the individual communicates and discusses the ideas with other learners and teachers (Yaşar, 2010: 17).

Table 1. "The Role of the Learner" in Québec's secondary education chemistry curriculum

Although educational tools are suggested by the teacher, it is important that students are fully engaged in them. They can only integrate new concepts and make connections between them and students' prior knowledge. In learning concepts, adaptation of their prior knowledge and the knowledge they used in concept learning is up to the students.

With the help of a situation that arouses their interest, to give a specific role in an independent activity encourages students to use their reasoning, to discuss, and to make critical decisions.

This requires them to adopt such attitudes as the spirit of initiative, creativity, autonomy and mental stability.

To do so, they have to use more than one inner resource (knowledge and techniques, skills, approaches, strategies and attitudes) and to build them.

If necessary, they use human resources in close surroundings or they choose material resources used in learning processes, they research diverse knowledge. In some occasions, it can be interesting to get them out of the school or family dwelling. Their environment, industry, experts, and museums allow them to open up to the world and to consider different perspectives. 
When learners do lab work, it is important to use, insofar as possible, suitable techniques. This is how we should understand learners' "use of knowledge resources and teaching materials." If learners use control or correction tools, teachers must consider the ambiguities of scale, the user's relationship to the device and the environment. Learners have to make measurements using sufficient meaningful numbers and show analysis results based on errors related to them. Every time, they have to apply security standards, and during lab work, they must do exercises carefully. In suspicious situations, they should call on their teachers, or the technician in practical work, or rely on equipment that can prevent interference

It is understood that the "learner roles" identified as learner acquisitions in Québec's curriculum in Appendix 1a-1e coincide with the "learner roles" given in Table 1. These coincidences are presented below:

Although educational tools are suggested by the teacher, it is important that students are fully engaged in them. They can only integrate new concepts and make connections between them and students' prior knowledge. In learning concepts, adaptation of their prior knowledge and the knowledge they used in concept learning is up to the students. This point requires learners' "to be active in the learning environment". This result is compatible with the study by Savery and Duffy (1996); cited by [Yaşar, 2010: 18] and Yaşar (1998: 698).

With the help of a situation that arouses their interest, giving students a specific role in an independent or assisted activity encourages them to use their reasoning, to discuss, and to use critical decisions. This point means learners' "take responsibility for the learning process". This result is compatible with the study by Savery and Duffy (1996); cited by [Yaşar, 2010: 18] and Yaşar (1998: 698).

This requires them to adopt such attitudes as the spirit of initiative, creativity, autonomy and mental stability. This means that learners' "apply what they learn in new environments". This result is compatible with the study by Savery and Duffy (1996); cited by [Yaşar, 2010: 18] and Yaşar (1998: 698).

To do so, they have to use more than one inner resource (knowledge and techniques, skills, approaches, strategies and attitudes) and to build them. From that point, we can understand learners' "to use knowledge resources and teaching materials". This result is compatible with the study by Savery and Duffy (1996); cited by [Yaşar, 2010: 18] and Yaşar (1998: 698).

If necessary, they can use human resources for nearby surroundings or choose material resources used in learning processes, to research diverse fields of knowledge. On some occasions, it can be interesting to get them out of school or family dwellings . Their environment, industry, experts, and museums allow them to open up to the world and to consider different perspectives. This allows them "to take advantage of every opportunity and possibility". This result is compatible with the study by Savery and Duffy (1996); cited by [Yaşar, 2010: 18] and Yaşar (1998: 698).

When learners do lab work, it is important to use, insofar as possible, suitable techniques. If they use control or correction tools, they have to consider ambiguities of measurements, their relationship with the device user the environment. They have to make measurements using sufficient meaningful numbers and show analysis results based on errors related to them. Every time, they must apply security standards, and during lab work, they must do exercises carefully. In suspicious situations, they should call on their teachers or the technician in practical applications or rely on equipment that can prevent interferences. This is how we should understand learners' "using knowledge resources and teaching materials". This result is compatible with the study by Savery and Duffy (1996); cited by [Yaşar, 2010: 18] and Yaşar (1998: 698).

\subsection{Limitations}

The study is restricted to the secondary education chemistry curriculum of the province of Québec / Canada.

\section{Conclusions and Discussion}

It was found at the end of the research that there exist parallelisms between the "learner roles" implied among the acquisitions (Appendix 1a-1e) in the above-mentioned course program and the "student role" presented in Table 1. It was determined that these parallelisms and "constructivist learner roles" are mostly in harmony with each other. 
These harmonious constructivist learner roles are the following: $i)$ the individual takes the control of the learning process, ii) the individual is selective, constructive and active in the learning process, iii) the individual carries out his/her responsibilities in constructive learning environments, iv) the individual, constructs a meaning in his/her mind for knowledge acquired in the construction process and appropriates that knowledge, v) the individual communicates and discusses issues with other learners and teachers. These findings are in parallel with the findings in the relevant literature (Brooks \& Brooks, 1993; Ülgen, 1994; Lind et al., 1996: 211; cited by Şaşan, 2002; Savery and Duffy, 1996; cited by Yaşar, 2010: 18; Marlowe \& Page, 1998; Yaşar, 1998: 698; Şaşan, 2002; Taber, 2006).

Moreover, in the appropriation of these constructivist learner roles, an expression of a clue was found, which implied that it was aimed to endow students with the perspective of History-Technology-Society as a particular approach for science teaching and as a background framework for the construction of objectives. This clue was Albert Einstein's following statement: "Every day I remind myself that my inner and outer life are based on the labors of other men, living and dead, and that I must exert myself in order to give in the same measure as I have received and am still receiving"'[PSQ].

In other words, clues about the philosophy that "labours of other people, living and dead, have influenced my personal progress, and as a payback, I extracted atomic energy and presented it to the service of humanity" may also be found.

When Einstein's statement (History-Technology-Society) is addressed from the perspective of History, the following are understood;

- "History"; from the expression "my inner and outer life are based on the labours of other men, living and dead", or in other words, Isaac Newton's statement "rise by standing on giants' shoulders" [RSGS] referring to John Wallis,

- "Technology", from the expression "I must exert myself in order to give in the same measure as I have received and am still receiving",

- "Society", or "sense of responsibility to the society" from the expression "Every day I remind myself that I must exert myself in order to give".

From the clues about the philosophy expressed by Einstein, it is inferred that History stands for the past, whereas Technology stands for the present and Society stands for the future. From his act of thinking every day, on the other hand, it is understood that "thinking stands for the time, which encapsulates the past, the present and the future". That is, it is understood that ideas that are products of lives in the past are "History", products of these ideas in the present are "Technology", and presentation of these products to the service of humanity is "Society".

The clue expression "generalization" [PSQ] pointed above is presented in the course program in the form of "implicit program". Implicit programs can be integrated with normal education programs if they are designed in a way to reveal individuals' varying needs and creativities (Demirel; 2011: 8). It is inferred from this point that the curriculum development specialists in Québec were capable of analyzing implicit programs and rendering them a part of normal education programs. This way, students can be enabled to obtain information and improve themselves on extracurricular issues (Demirel; 2011: 7). This improvement is contingent upon the student's awareness about; i) what the learning duties are, ii) the importance of acquiring them in a sequential order, iii) and his responsibility for learning activities" (Ülgen, 1994: 174). In other words, it is contingent upon the learner's knowledge of "learner roles", which, as Posner (1995) suggests, need to be in the form of "implicit program" (cited by Demirel, 2011: 7). Implicit program is a very wide notion that also covers extracurricular activities (Demirel; 2011: 7). In other words, an implicit program is the qualities that students attain through knowledge, opinions and practices that emerge in the learning-teaching process, other than the objectives and activities specified in the official program (Yüksel, 2004: 10-11). Acquisition of these qualities in the form of implicit program may serve as a model to secondary education chemistry curricula of other countries and states. For these reasons, it is believed that this study will contribute to the literature.

\section{Suggestions}

The above-mentioned clue in the appropriation of constructivist learner roles can be generalized as the contribution of teaching programs to education programs. The inclusion of this expression in the form of an implicit program aimed at endowing students with constructivist learner roles in the program might serve as a model to secondary education chemistry curricula of other countries and states. 


\section{References}

Akar, H., \& Yıldırım, A. (2004). Oluşturmacı öğretim etkinliklerinin Sınıf Yönetimi Dersi’nde Kullanılması: Bir eylem araştırmasi. [use of constructive teaching activities in Classroom Management Course: A research of action]. Sabancı University Conference of Good Samples, Turkey.

Avenstrup, R. (2004). The challenge of curriculum reform and implementation: Some implications of a constructivist approach. Retrieved October 18, 2012, from http://tedp.meb.gov.tr

Aydin, A. (2012). Learning approaches and models adopted in the high school chemistry curricula in several nations. The Journal of Academic Social Science Studies, 5(8), 143-169.

Bağcı-Kılıç, G. (2001). Oluşturmacı fen öğretimi [Constructive Science Teaching]. Educational Science in Theory and Practice, 1, 9-22.

Baker, E. (2007). Constructivism and learning. In Mcgaw, B., \& Peterson, P. (Eds.), International Encyclopaedia of Education 3th Edition, Oxford, England: Elsevier (in print). Retrieved October 22, 2012, from http://folk.uio.no/sveinsj/Constructivism_and_learning_Sjoberg.pdf

Brooks, J. G., \& Brooks, M. G. (1993). In search for understanding the case for constructivist classroom. Alexandria, Virginia: ASCD.

Büyüköztürk, S., Çakmak, E. K., Akgün, Ö. E., Karadeniz, S., \& Demirel, F. (2008). Bilimsel Araşttrma Yöntemleri (1. Baskı) [Scientific research methods] (1st ed). Ankara: Pegem Akademi.

Demirel, Ö. (2011). Eğitimde Program Geliştirme (17. Baskl) [Program Development in Education] (17th ed.) . Ankara: Pegem Akademi.

Demle [D] (2013, February 13). Eğitim ile ilgili sözler [Quotes on education]. Retrieved February 13, 2013, from http://demle.net/tag/E\%C4\%9Fitim/

Deryakulu, D. (2001). Yapıcı Öğrenme [Constructive learning]. Ankara: Eğitim Sen Yayınları.

Erickson, G. (2001). Research programmes and the student science learning literature. In Millar, R., Leach, J., \& Osborne, J. (Eds.), Improving Science Education - the contribution of research Buckingham: Open University Press.

Filozoflar ve Düşündüren Sözleri [Philosophers and Their Suggestive Quotes] [PSQ] (2012, September 9). "Dünyayl Nasıl Görüyorum" [How do I see the World]. Retrieved September 9, 2012, from http://dusundurensozler.blogspot.com/2008/02/dnyay-nasl-gryorum.html.

Free your Mind and Think. [FMT]. (2013, January 19). What is the World for Einstein (picture). Retrieved January 19, 2013, from http://www.google.com.tr/imgres?q=FREE+your+MIND+and+THINK\&hl=tr\&sa=X\&tbo=d\&rlz=1R2AD FA_trTR459\&tbm=isch\&tbnid=-

Gündoğdu, A. (2010). Yapılandırmacı yaklaşımda öğretmenin, öğrencinin ve velinin rolü [The role of teacher, learner and parents in constructive approach]. Eğitime Bakış (Ĕgitim-Öğretim ve Bilim Araştırma) Dergisi [View on Education (Education-Teaching and Science Research) Magazine], 17, 15-19.

Gürdal, A., \& Önen, F. (2010). Yeni Fen ve Teknoloji Öğretimi Programı [New science and technology program]. Retrieved $\quad$ December $\quad 30, \quad 2012, \quad$ from http://www.f2e2-ogretmen.com/inservice/Seminer_Calistaylar/yapilandirmacilik\%20eklenmis.pdf.

Gustave, N. T. (2003). Mémoire de Diplôme d'Études Approfondies en Sciences de l'Education. Chaire UNESCO en Sciences de l'Education, Université Cheikh Anta Diop de Dakar \& École Normale Supérieure, Educational Term: 2003/2004. Retrieved October 21, 2012, from http://www.fastefportedu.ucad.sn/cuse/cr/memthes/tatchou.pdf

Hayat problem çözmektir [Life is to Solve the Problem][LSP] (2013, January 12). YapıKredi kültür sanat yayincllk [YapıKredi culture art publishing]. Retrieved from http://www.ykykultur.com.tr/kitap/hayat-problem-cozmektir

İnam, A. (2012, May). “Artık öğrenemiyorsak ölmüşüz demektir” [If we do not learn any more, this means that we have died]. Retrieved November 5, 2012, from http://www.yazaroku.com/fyasam-magazin/ahmet-inam/24-05-2012/artik-ogrenemiyorsak-olmusuz-demekt ir/449900/.aspx 
İnsan Özgürlüğe Mahkumdur [Man is Condemned to Freedom][MCF] (2012, December 25). Retrieved December 25, 2012, from http://www.meshursozler.com/oku/5156-insan-ozgurluge-mahkumdur.html

Kaya, Z., Tüfekçi., \& Bilasa, P. (2010). Yapılandırmacı yaklaşımda öğretmenin, öğrencinin ve velinin rolü [The role of teacher, learner and parents in constructive approach]. Eğitime Bakıs (Ĕgitim-Öğretim ve Bilim Araştırma) Dergisi [View on Education (Education-Teaching and Science Research) Magazine], 17, 15-19.

Khoza, S. B. (2013). Learning Outcomes as understood by 'Publishing Research' facilitators at a South African university. Mevlana International Journal of Education (MIJE), 3(2), 1-11, http://dx.doi.org/10.13054/mije.13.09.3.2

Marlowe, A. B., \& Page, L. M. (1998). Creating and sustaining the constructivist classroom. California: Corwin Press.

Marois, P. (1998). Programme d'études Chimie 5é Secondaire. Ministére de l'éducation, Gouvernement du Québec. $\quad$ Retrieved September $\quad 9, \quad 2012, \quad$ from http//www.mels.gouv.qc.ca/dfga/disciplines/chimie/pdf/programme/chimie5.pdf

Oliver, A. I. (1971). When does a curriculum need to be changed? In curriculum improvement: A guide to problems principles, and procedures. (Mead \& Company). New York: Dodd.

Orhan, A. T. (2007). Fen Eğitiminde Alternatif Ölçme ve Değerlendirme Yöntemlerinin İlköğretim Öğretmen Adayı, Öğretmen ve Öğrenci Boyutu Dikkate Alınarak İncelenmesi [Analyzing alternative measure and evaluation methods in science education by considering primary teacher candidates, teacher and learner aspects]. Yayınlanmamış Doktora Tezi [Unpublished Dissertation Thesis], Gazi Üniversitesi Eğitim Bilimleri Enstitüsü [Gazi University Institute of Education Science], Turkey.

Perkins, D. (1999). The many faces of constructivism. Educational Leadership, 57(3), 6-11.

Programme de Formation de l' École Québécoise (PFÉQ). (2012, October 09). Domaine de la mathématique, de la science et de la technologie. Retrieved October 9, 2012, from http://www.mels.gouv.qc.ca/sections/programmeformation/secondaire2/medias/6d-pfeq_applictech.pdf

Rise by Standing on Giants' Shoulders [RSGS]. (2013, January 12). Google Academic Main Page. Retrieved January 12, 2013, from http://scholar.google.com.tr/

Şaşan, H. H. (2002). Yapılandırmacı Öğrenme [Constructive learning]. Yaşadıkça Eğitim Dergisi, 74-75, 49-52.

Shunk, D. H. (1996). Learning theories: An educational perspective (2nd ed). New Jersey: Prentice-Hall, Inc.

Skamp, K., \& Peers, S. (2012). Implementation of science based on the 5E learning model: Insights from teacher feedback on trial Primary Connections units. The $43^{\text {th }}$ Annual Conference of the Australasian Science Education Research Association (ASERA), University of the Sunshine Coast, Australia; $27^{\text {th }}-30^{\text {th }}$ June, 2012.

Taba, H. (1962). Curriculum development: Theory and practice. (Brace \& World). New York: Harcourt.

Taber, K. S. (2006). Beyond constructivism: The progressive research programme into learning science. Studies in Science Education, 42, 125-184.

Ülgen, G. (1994). Eğitim Psikolojisi: Kavramlar, ilkeler, metotlar, teoriler ve pratikler [Educational Psychology: Concepts, principles, methods, theories and practices]. Ankara: Laser Offset.

Vygotsky, L. (1994). The development of thinking and concept formation in adolescence. In R. Van der Veer, \& J. Valsiner (Eds.), The Vygotsky reader (pp. 175-184). Oxford: Blackwell.

Yaşar, Ş. (1998, September). Yapısalcı Kuram ve Öğrenme-Öğretme Süreci [Constructive theory and learning-teaching process]. The Congress of National Educational Sciences VII, Konya, Turkey.

Yaşar, Ş. (2010). Yapılandırmacı yaklaşımda öğretmenin, öğrencinin ve velinin rolü [The role of teacher, learner and parents in constructive approach]. Ĕgitime Bakış (Ĕgitim-Öğretim ve Bilim Araştırma) Dergisi [View on Education (Education- Teaching and Science Research) Magazine], 17, 15-19.

Yıldırım, A., \& Simsek, H. (1999). Sosyal Bilimlerde Nitel Araştırma Yöntemleri [Qualitative research methods in social sciences]. Ankara: Seçkin Kitapevi.

Yıldırım, A., \& Simsek, H. (2004). Sosyal Bilimlerde Nitel Araştırma Yöntemleri [Qualitative research methods in social sciences]. Ankara: Seçkin Kitapevi. 
Yüksel, S. (2004). Örtük Program: Eğitimde Saklı Uygulamalar (1. Baskl) [Hidden Curriculum: Hidden Practices in Education] (1th edition). Ankara: Nobel Yayın Dağııım.

\section{Appendix}

Appendix 1. The contribution of the chemistry program to the educational program (Apport du programme de chimie au Programme de formation)

Appendix-1a. Goals of the educational program (Visées du programme de formation)

\section{Student (élève);}

Construction of identity (Structuration de l'identité)

Building a world view (Construction d'une vision du monde)

Improving operational power (Développement du pouvoir d'action)

Appendix-1b. General fields of education (Domaines généraux de formation)

\begin{tabular}{l}
\hline Media (Médias) \\
\hline Environment and consumption (Environnement et consommation) \\
Entrepreneurship and guidance (Orientation et entrepreneuriat) \\
Health and wealth (Santé et bien-être) \\
Living together and citizenship (Vivre-ensemble et citoyenneté) \\
\hline
\end{tabular}

Appendix-1c. Transversal Skills (Compétences transversales)

Communication Skilsl (Compétence de l'Ordre de la Communication)

Communicating properly (Communiquer de façon appropriée)

Personal and Social Skills (Compétences d'Ordre Personnel et Social)

Realization of potential (Actualiser son potentiel)

Cooperation (Coopérer)

Methodological Skills (Compétences d'Ordre Méthodologique)

Exploring information and communication technologies (Exploiter les technologies de

l'information et de la communication)

Using effective study methods (Se donner des méthodes de travail efficaces)

Intellectual Skills (Compétences d'Ordre Intellectuel)

Exploiting information (Exploiter l'information)

Solving problems (Résoudre des problèmes)

Using critical judgement (Exercer son jugement critique)

Putting creative thinking into practice (Mettre en oeuvre sa pensée créatrice)

Appendix-1d. Learning Fields associated with Chemistry (Chimie Domaines d'apprentissage)

Mathematics, science and technology (Mathématique, science et technologie)

The social universe (Univers social) 


\section{Arts (Arts)}

Personal development (Développement de la personne)

Career development (Développement de la professionnel)

Languages (Langues)

Appendix-1e. Disciplinary Skills in Chemistry (Compétences disciplinaires en chimie)

To solve problems and seek solutions in chemistry (Chercher des réponses ou des solutions à des problèmes relevant de la chimie)

To benefit from the knowledge of chemistry (Mettre à profit ses connaissances en chimie)

To discuss issues in chemistry with the help of the languages used in science and technology (Communiquer sur des questions de chimie à l'aide des langages utilisés en science et en technologie)

Appendix 2. Constructivist Learner Roles

To be active in the educational environment

To take responsibility for the learning process

To take advantage of every opportunity and possibility

To evaluate themselves and the group members they work with objectively

To accept all criticism of themselves with tolerance

To apply what they learn to new environments

To use knowledge sources and teaching materials

Learning actively (mentally and physically) is obvious in most cases

Discussing one's own and others' ideas

Using ideas to try to understand new events/ phenomena

Reasoning about evidence

Modifying ideas in the light of evidence

Developing 'bigger' ideas from 'smaller' ones

(Savery \& Duffy, 1996; cited by Yaşar, 2010: 18; Yaşar, 1998:698; Skamp \& Peers, 2012)

\section{Copyrights}

Copyright for this article is retained by the author(s), with first publication rights granted to the journal.

This is an open-access article distributed under the terms and conditions of the Creative Commons Attribution license (http://creativecommons.org/licenses/by/3.0/). 